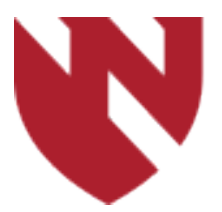

September 2020

\title{
Urology Medical Education: A Decade Later
}

\author{
Jay Jiang \\ University of Nebraska Medical Center \\ David Fu \\ University of Nebraska Medical Center \\ Alexandra Colbin \\ University of Nebraska Medical Center \\ Chad LaGrange \\ University of Nebraska Medical Center \\ Gina Badalato \\ Columbia University Medical Center
}

See next page for additional authors

Tell us how you used this information in this short survey.

Follow this and additional works at: https://digitalcommons.unmc.edu/gmerj

Part of the Higher Education Commons, and the Medicine and Health Sciences Commons

\section{Recommended Citation}

Jiang, J., Fu, D., Colbin, A., LaGrange, C., Badalato, G., , Deibert, C. Urology Medical Education: A Decade Later. Graduate Medical Education Research Journal. 2020 Sep 29; 2(1).

https://digitalcommons.unmc.edu/gmerj/vol2/iss1/45

This Conference Proceeding is brought to you for free and open access by DigitalCommons@UNMC. It has been accepted for inclusion in Graduate Medical Education Research Journal by an authorized editor of DigitalCommons@UNMC.For more information, please contact digitalcommons@unmc.edu. 


\section{Urology Medical Education: A Decade Later}

Creative Commons License

(c) (i)@(ङ)

This work is licensed under a Creative Commons Attribution-Noncommercial-No Derivative Works 4.0 License.

Authors

Jay Jiang, David Fu, Alexandra Colbin, Chad LaGrange, Gina Badalato, and Christopher Deibert 


\section{The Impact of a Dermatology Department on Basal Cell Carcinoma Diagnoses \\ Dillon Clarey ${ }^{1}$, Ashley Wysong ${ }^{1}$ \\ ${ }^{1}$ University of Nebraska Medical Center, Department of Dermatology}

Mentor: Ashley Wysong

Program: Dermatology

Type: Original Research

Background: Basal cell carcinoma (BCC) accounts for approximately 4.3 million cases annually in the U.S., more common than any other cancer. The emergence of Mohs micrographic surgery as a treatment modality has had a profound impact on the way BCC is managed. Previous reports have studied the cost effectiveness of Mohs micrographic surgery in comparison to surgical excision and outpatient versus operating room setting. The objective of this study was to evaluate trends in management of $\mathrm{BCC}$ before and after the initiation of a department of dermatology at our large academic medical center.

Methods: Cases of BCC, identified with ICD-9 and ICD-10 codes, from July 1st, 2013, (fiscal year (FY) 2013) to January 2020 were obtained via retrospective chart review. Variables collected included number of cases, service line, location (inpatient, outpatient), charges, costs, and expense net revenue, among others.

Results: The average number of cases per year from FY13-FY18 and FY19-FY20 increased. There were differences in charges per case, expense net revenue per case, percent managed outpatient versus inpatient (ambulatory versus main operating room), and service managing.

Conclusion: The addition of a department of dermatology at UNMC has significantly increased the total number of BCCs diagnosed and managed annually. Mohs micrographic surgery allows for complete margin assessment and is done in the outpatient setting, serving as a shift in management from surgical excision used more often in the operating room setting.

https://doi.org/10.32873/unmc.dc.gmerj.2.1.042

\section{Urology Medical Education: A Decade Later \\ Jay Jiang ${ }^{1}$, David Fu', Alexandra Colvin ${ }^{1}$, Chad LaGrange1, Gina Badalato², Christopher Deibert ${ }^{1}$ ${ }^{1}$ Department of Surgery, Division of Urologic Surgery, University of Nebraska Medical Center, ${ }^{2}$ Department of Urology, Columbia University Medical Center, New York, NY}

\section{Mentor: Christopher Diebert}

Program: Surgery, Division of Urologic Surgery

Type: Original Research

Background: Urological education for medical students is critical as we face a growing geriatric population with increasing urological needs. The past decade has seen many schools overhaul their medical curriculum and changes that impacts the quality of urological education. Urology medical student education was first examined in 2006 and then reevaluated in 2014.

Methods: We emailed all 164 listed urology program coordinators in the AUA residency program directory to ask them to fill out an IRB approved 22 question survey in order to further examine the current status of urologic education in US allopathic schools.

Results: In total, 33/136 (24\%) program directors responded with $84 \%$ stating that medical students receive formal exposure to urology through either lectures or clinical rotations. The average lecture hours spent during pre-clinical urology topics is 5 hours. 56\% replied their school has a formal core curriculum for their clinical clerkship, with $70 \%$ based off the AUA national core curriculum. $100 \%$ offered a clinical rotation in urology. Research opportunities are available at $90 \%$ of programs. $55 \%$ report urology exposure remains stable compared to five years ago. $27 \%$ think it has decreased, while $13 \%$ note increased interest. Urology student groups have increased from $29 \%$ of schools to $90 \% .90 \%$ agree that students can graduate without Urology clinical exposure and $72 \%$ think urology education is inadequate.

Conclusion: More effort is needed so that students are exposed and ready to deal with the aging population. Possible solutions are increased push for pre-clinical education, visibility of AUA student education, and marketing of urology as a specialty.

https://doi.org/10.32873/unmc.dc.gmerj.2.1.043

\section{Epidural Steroid Injection for Cervical Radiculopathy Preceding a New Diagnosis of Multiple Sclerosis Clayton Damme ${ }^{1}$, Michael Lankhorst ${ }^{1}$ \\ ${ }^{1}$ University of Nebraska Medical Center, Department of Anesthesiology}

Mentor: Michael Lankhorst

Program: Anesthesiology

Type: Case Report

Background: Epidural steroid injections treat chronic spine pain and radiculitis. Commonly cited risks include hematoma, spinal cord trauma, abscess, unintentional dural puncture, and spinal cord ischemia. To our knowledge, there have been no previous case reports of an exacerbation of MS following an epidural injection of plain steroids. We present a patient with no previous history of MS who, despite presenting with classic symptoms of cervical radiculopathy and correlative imaging, was subsequently diagnosed with MS after treatment with a cervical epidural steroid injection (CESI).

Methods: Patient informed consent was obtained for this case report.

Case Report: A 40-year-old male was referred with dull neck pain and associated right upper extremity numbness in a C6 dermatomal pattern. Cervical spine MRI was consistent with a diagnosis of cervical spondylosis with radiculopathy and he then underwent CESI at the C6-7 level. Within 48 hours his pain resolved but he developed pathologic upper and lower motor neuron signs. MRI revealed active spinal cord demyelination (Figure 1) and new brain lesions. He was subsequently diagnosed with MS.

Discussion: Although we saw a temporal relationship between the CESI and the 